\title{
Story As a Media for Improving Students' Learning Outcomes in Indonesian Class IV SD Negeri Dukuhlo 01, Bulakamba Sub-District, Brebes Regency
}

\author{
Kartini \\ SD Negeri Dukuhlo 01 \\ kartinioppoas@gmail.com
}

\section{Article History}

received $3 / 12 / 2020$

\begin{abstract}
The purpose of this study is to improve students' learning outcomes in Mapel Bahasa Indonesia Elementary School grade IV with fairytale media. The research conducted is class Action Research ( PTK) as many as three cycles, with each cycle consists of two meetings. The stages of each cycle are planning, implementation, observation and reflection. Each meeting is conducted pre test and post test to know the development of students. In cycle I students who completed after doing post tests by $60 \%$. In cycle II students completed after post-test by $80 \%$. In cycle III students who completed after doing post tests by $90 \%$. These results show that the medium of learning fairy tales in Indonesian subjects can improve the learning outcomes of grade 4 students at SD Negeri Dukuhlo 01 Bulakamba Subdistrict, Brebes.
\end{abstract}

Keywords: learning outcomes, fairytales

\section{Abstrak}

Tujuan dari penelitian ini adalah untuk meningkatkan hasil belajar siswa Bahasa Indonesia Sekolah Dasar kelas IV dengan media dongeng.Penelitian yang dilakukan adalah Penelitian Tindakan kelas ( PTK ) sebanyak tiga siklus,dengan setiap siklusnya terdiri dari dua pertemuan.Tahapan dari setiap siklusnya adalah perencanaan,pelaksanaan,observasi dan refleksi.Setiap pertemuan dilakukan pre test dan post test untuk mengetahui perkembangan peserta didik.Pada siklus I peserta didik yang tuntas setelah melakukan post tes sebesar $60 \%$ .Pada siklus II peserta didik yang tuntas setelah melakukan post tes sebesar $80 \%$.Pada siklus III peserta didik yang tuntas setelah melakukan post tes sebesar $90 \%$. Hasil ini menunjukkan bahwa media pembelajaran dongeng pada mata pelajaran Bahasa Indonesia dapat meningkatkan hasil belajar siswa kelas 4 di SD Negeri Dukuhlo 01 Kecamatan Bulakamba Kabupaten Brebes.

Kata kunci: hasil belajar, dongeng 


\section{PENDAHULUAN}

Saat pandemi melanda, negeri kita tercinta membawa perubahan disemua sektor,begitu juga pada sektor pendidikan dimana sekarang anak-anak tidak bisa menikmati pembelajaran secara luring ( tatap muka ). Kebijakan pemerintah untuk dirumah saja,menjaga jarak membuat dunia pendidikan tidak bisa melaksanakan pembelajaran tatap muka,sudah hampir 2 tahun pembelajaran dilaksanakan secara daring.Setelah melaksanakan hampir 2 tahun pembelajaran daring ternyata banyak kendala yang dihadapi para pendidik,terutama para guru Sekolah Dasar SD Negeri Dukuhlo 01.

Diantara kendala yang sering dihadapi para guru yakni kurangnya sarana dan prasarana pembelajaran daring,seperti minimnya ketersediaan leptop,juga banyak para siswa yang tidak memiliki handphone.Saat pembelajaran daring banyak materi yang susah diterima oleh siswa,karena proses pembelajaran pun berjalan tidak maksimal,sinyal yang kurang mendukung menyebabkan penyampaian materi tersendatsendat.Bagaimana cara guru dapat menyampaikan materi dengan baik,sehingga bisa diterima oleh siswanya dengan baik pula.Proses pembelajaran yang baik harus disesuaikan dengan karakteristik peserta didik agar siswa dapat menangkap materi dengan baik pula,pembelajaran juga harus kreatif dan tidak monoton sehingga siswa tidak bosan dengan materi yang disampaikan.Media dan penyampaian materi juga harus kreatif dan bervariasi agar siswa bisa ikut aktif dalam pembelajaran.Penggunaan berbagai teknik dan metode yang inovatif tentu dapat menciptakan situasi pembelajaran yang kondusif ,siswa dalam kaitan ini dapat terlibat secara langsung dalam menyerap informasi dan menyatakan kembali hasil rekaman informasi yang diperolehnya sesuai dengan kemampuan individu peserta didik.Melalui pembelajaran yang dinamis diharapkan akan tercipta suatu bentuk komunikasi lisan antara siswa yang satu dengan yang lainnya yang terpola melalui ketrampilan menyimak,berbicara,membaca,dan menulis sehingga suasana pembelajaran tidak jenuh. Bercerita (mendongeng) merupakan kegiatan yang sangat bermanfaat,kegiatan ini sangat menyenangkan dan sekaligus merangsang imajinasi siswa.Langkah-langkah bercerita antara lain memilih cerita,mempersiapkan diri untuk bercerita,menambah peraga,dan menyampaikan cerita.Teater pembaca adalah presentasi pembacaan naskah drama oleh sekelompok siswa.Langkah-langkah kegiatannya yaitu memilih naskah,latihan dan presentasi

Menurut Kak Bimo (2011:18), kata dongeng berarti cerita rekaan/tidak nyata/fiksi, seperti fabel (binatang dan benda mati), sage (cerita petualangan), hikayat (cerita rakyat), legenda (asal- usul), mite (makhluk halus), epos, (cerita besar; Mahabharata, Ramayana, Saur Sepuh, Tutur Tinular). Dalam bukunya Kak Bimo menyatakan bahwa sebutan untuk orang yang melakukan cerita (pencerita) dan yang melakukan dongeng (pendongeng) dipakai secara bersamaan atau dianggap sinonim. Dongeng merupakan cerita sederhana yang tidak benar-benar terjadi. Dongeng bersifat tidak nyata, sebab dongeng itu sendiri tercipta dari imajinasi hasil pemikiran seseorang. Di dalam dongeng biasanya terdapat penyampaian pesan moral (pendidikan) dan sifatnya menghibur. Menurut Hana (2011:14), dongeng berarti cerita rekaan, tidak nyata, atau fiksi, seperti fabel (binatang dan benda mati), saga (cerita petualangan), hikayat (cerita rakyat), legenda (asal usul), mythe (dewadewi, peri, roh halus), epos (cerita besar seperti Mahabharata dan Ramayana). Rampan (2012:104) menyatakan bahwa cerita anak termasuk dongeng untuk anak, biasanya membawa sebuah pesan. Cerita adalah uraian, gambaran, atau deskripsi tentang peristiwa atau kejadian tertentu (Aprianti Yofita, 2013:80). Cerita merupakan salah satu bentuk sastra yang memiliki keindahan dan kenikmatan tersendiri. Akan menyenangkan bagi anak-anak maupun orang dewasa, jika pengarang, pendongeng, dan penyimaknya samasama baik. cerita adalah salah satu bentuk sastra yang bisa dibaca atau hanya didengar oleh orang yang tidak bisa membaca (Abdul Azis, 2013:8). Sedangkan sebuah cerita anak yang unggul antara lain mengandung nilai personal dan nilai pendidikan bagi pembacanya, yaitu kalangan anak- 
anak. Dongeng diceritakan terutama untuk hiburan.Unsur-unsur intrinsic dalam dongeng.

Menurut Musfiroh (2005:95-115), dipandang dari berbagai aspek, sebuah dongeng atau cerita memiliki banyak manfaat antara lain sebagai berikut: 1) Membantu Pembentukan Pribadi dan Moral Dengan memilih dongeng yang isi ceritanya bagus, maka akan tertanam berbagai nialai-nilai moral yang baik. Setelah mendongeng, sebaiknya pendongeng menjelaskan mana yang baik yang patut ditiru dan mana-mana saja yang buruk dan tidak perlu ditiru dalam kehidupan sehari-hari. Berbagai tindak kenaklan dapat dikurangi dari menanamkan perilaku dan sifat yang baik dari mencontoh karakter ataupun sifat-sifat perilaku di dalam cerita dongeng. Mendongeng mungkin memiliki efek yang lebih baik daripada mengatur anak dengan cara kekerasan (memukul, mencubit, menjewer, membentak, dan lain-lain). 2) Menyalurkan Kebutuhan Imajinasi Anak membutuhkan penyaluran imajinasi tentang berbagai hal yang selalu muncul dalam pikiran mereka. Pada saat menyimak cerita, imajinasi mereka mulai dirangsang. Mereka membayangkan apa yang terjadi dan tokoh yang terlibat dalam cerita tersebut. Imajinasi yang dibangun anak saat menyimak cerita memberikan pengarauh positif terhadap kemampuan mereka menyelesaikan masalah secara kreatif. Sayang sekali saat ini jarang sekali kaset tape atau CD audio dongeng maupun cerita suara yang di jual di toko kaset dan CD. Atau, mungkin sudah tidak ada sama sekali. Padahal cerita-cerita dalam bentuk suara dapat membuat anak berimajinasi membayangkan bagaimana jalan cerita dan karakternya. Anak-anak akan terbiasa berimajinasi untuk memvisualkan sesuatu di dalam pikiran sehingga dapat menjabarkan atau menyelesaikan suatu permasalahan. 3) Memacu Kemampuan Verbal Selama menyimak cerita, anak dapat belajar bagaimana bunyi-bunyi yang bermakna diajarkan dengan benar, bagaimana kata-kata itu disusun secara logis dan mudah dipahami, bagaimana konteks dan koteks berfungsi dalam makna. Cerita dapat juga mendorong anak untuk senang bercerita atau berbicara. Mereka dapat berlatih berdialog, berdiskusi antar teman untuk menuangkan Kembali gagasan yang disimaknya.

\section{METODE}

Penelitian tindakan kelas (PTK) atau dalam Bahasa Inggris dikenal dengan classroom action research merupakan suatu pendekatan terhadap kegiatan belajar berupa sebuah tindakan, yang sengaja dimunculkan dan terjadi dalam sebuah kelas secara bersama. Penelitian tindakan kelas ini dilaksanakan di SD Negeri Dukuhlo 01 pada kelas IV Semester II tahun pelajaran 2019/2020. Subjek dan Objek Penelitian Subjek penelitian ini seluruhnya adalah siswa kelas IV SD Negeri Dukuhlo 01 tahun ajaran 2019/2020 yang berjumlah 30 siswa, . Prosedur Penelitian Prosedur penelitian yang digunakan dalam penelitian ini adalah prosedur penelitian tindakan kelas (PTK), yang mengacu pendapat Suharsimi Arikunto, (2012:16) yang mengatakan bahwa "Terdapat empat tahapan yang lazim dilalui dalam melaksanakan Penelitian Tindakan Kelas yaitu, (1) perencanaan, (2) pelaksanaan, (3) pengamatan, dan (4) refleksi”.

\section{HASIL DAN PEMBAHASAN}

Pelaksanaan tindakan dalam penelitian ini didapatkan hasil diantaranya adalah perubahan tingkah laku siswa pada saat pembelajaran, perubahan cara mengajar guru dan perubahan hasil belajar dan siswa. Secara keseluruhan, perubahan tersebut akan dijelaskan lebih lanjut pada bagian ini. Berdasarkan hasil observasi terhadap aktivitas siswa dapat dilihat adanya kemajuan yang sangat baik. Keaktivan siswa berangsurangsur meningkat, keberanian siswa juga meningkat. Kreativitas dan inisiatif siswa meningkat dan 2,75 pada siklus I meningkat menjadi 3,55 pada siklus II. Berdasarkan hasil observasi kegiatan guru dapat diketahui bahwa ada peningkatan aktivitas guru. Kegiatan persiapan, pelaksanaan pembelajaran, dan pelaksanaan evaluasi pada akhir 
siklus jauh lebih baik dari pada siklus I. Hasil observasi menunjukkan adanya peningkatan yaitu 3,00 pada siklus I meningkat menjadi 3,63 pada siklus II. Hasil penelitian yang lainnya adalah nilai hasil berbicara siswa kelas IV. Nilai tersebut terdiri atas nilai berbicara siklus I dan siklus II sebagai kondisi akhir. Nilai berbicara pada siklus 1 adalah pada tabel 1.

Tabel 1. Hasil Siklus I

\begin{tabular}{cccc}
\hline No & Nilai & Jumlah Siswa & Persen \\
\hline 1. & Kurang dari 49 & 4 & 13,33 \\
2. & 50 s/d 59 & 12 & 40,00 \\
3. & 60 s/d 69 & 8 & 26,67 \\
4. & 70 s/d 79 & 5 & 16,67 \\
5. & 80 s/d 89 & 1 & 3,33 \\
6. & 90 s/d 100 & 0 & 0 \\
& JUMLAH & $\mathbf{3 0}$ & $\mathbf{1 0 0}$ \\
\hline
\end{tabular}

Berdasarkan hasil penelitian siklus I, siswa telah mengalami peningkatan dalam menggunakan lafal dan intonasi pada pembelajaran berbicara. Siklus I yang telah dilaksanakan ternyata masih terdapat kelemahan. Kelamahan tersebut adalah masih kurang tepatnya penggunaan lafal dan intonasi oleh siswa. Kelemahan tersebut diperbaiki dalam pembelajaran berbicara pada siklus II dengan Lebih menekankan pada penggunaan lafal dan intonasi yang baik. Siklus II dilaksanakan tindakan berupa penerapan penggunaan lafal dan intonasi yang baik dalam pembelajaran berbicara. Hasil nilai berbicara pada siklus II dapat dilihat pada tabel 2.

Tabel 1. Hasil Siklus II

\begin{tabular}{cccc}
\hline No & Nilai & Jumlah Siswa & Persen \\
\hline 1. & Kurang dari 49 & 0 & 0 \\
2. & 50 s/d 59 & 1 & 3,33 \\
3. & 60 s/d 69 & 8 & 26,67 \\
4. & 70 s/d 79 & 13 & 43,33 \\
5. & 80 s/d 89 & 6 & 20,00 \\
6. & 90 s/d 100 & 2 & 6,67 \\
& JUMLAH & $\mathbf{3 0}$ & $\mathbf{1 0 0}$ \\
\hline
\end{tabular}

Dalam pelaksanaan tahap siklus II, telah terjadi peningkatan yang cukup signifikan dalam hal penekanan penggunaan lafal dan intonasi yang baik dalam pelaksanaan siklus II ini banyak siswa telah melakukan pertanyaan langsung kepada guru sehingga siswa lebih berani dan termotivasi. Lebih jelasnya dapat dibuat grafik sebagai berikut: Dalam pelaksanaan tahap siklus II, telah terjadi peningkatan yang cukup signifikan dalam hal penekanan penggunaan lafal dan intonasi yang baik. Dalam pelaksanaan siklus II ini banyak siswa telah melakukan pertanyaan langsung kepada guru sehingga siswa lebih berani dan termotivasi. Sudono (2000) menyatakan bahwa dasar utama perkembangan bahasa adalah melalui pengalaman-pengalaman berkomunikasi yang kaya. Pengalaman tersebut akan menunjang faktor bahasa yang lain, yaitu mendengarkan, berbicara, membaca, dan menulis. Mendengar dan membaca merupakan keterampilan berbahasa reseptif, sedangkan berbicara dan menulis adalah kemampuan berbahasa ekspresif. Dari keterangan di atas, dapat dijelaskan bahwa seorang anak yang terus-menerus mendengarkan atau membaca dongeng akan menambah suplai kosa kata yang banyak. Jika kosa kata yang didapat terus bertambah dan anak semakin mengerti makna dari kosa kata tersebut, maka anak akan pandai mengekspresikan perasaannya atau keinginannya dengan cara berbicara atau 
SHEs: Conference Series 3 (4) (2020) 914 - 918

menuliskannya. Hal ini menjadikan dongeng sebagai media yang baik untuk menumbuhkan kemampuan berbahasa dan komunikasi pada anak.

\section{SIMPULAN}

Berdasarkan dari hasil paparan diatas maka dapat ditarik kesimpulan bahwa penggunaan pembelajaran menggunakan media Dongeng dalam pembelajara Bahasa Indonesia yang dilaksanakan di SD Negeri Dukuhlo 01 Kecamatan Bulakamba Kab, Brebes dapat meningkatkan prestasi belajar pada siswa kelas IV SD Negeri Dukuhlo 01. $\mathrm{Hal}$ ini dibuktikan dengan adanya peningkatan prestasi belajar siswa sejak siklus I sampai dengan akhir siklus II. siklus I persentase ketuntasan $60 \%$. Sedangkan pada siklus ke II presentase ketuntasan $90 \%$, penelitian ini dikatakan tuntas atau berhasil.

\section{DAFTAR PUSTAKA}

Henry Guntur Tarigan. 2008. Menyimak Sebagai Suatu Keterampilan Berbahasa. Bandung: Angkasa.

Isjoni. 2010. Guru Sebagai Motivator Perubahan. Yogyakarta: Pustaka Pelajar.

Umar mansur 2016,Inovasi Pembejaran Bahasa Indonesia Melalui Pendekatan Proses, Kumpulan Artikel terbaru

Ernawati. 2017. "Menumbuhkan Nilai Pendidikan Karakter Anak SD Melalui Dongeng (Fabel) Dalam Pembelajaran Bahasa Indonesia". Jurnal Pendidikan dan Pembelajaran Dasar. Vol.4,No.1, hlm 120-133.

Nurhayati, Hesti. 2015. "Peningkatan Keterampilan Menyusun Teks Cerita Fabel Dengan Teknik Rangsang Gambar". Jurnal Praktik Penelitian Tindakan. Vol. 5, No.3. HIm 13-19. Issn: 085-2172.

Sudono,Anggani (2000) Sumber Belajar Dan Alat Permainan, Jakarta Grasindo 